\title{
PREPARATION OF A NEW MOLECULARLY IMPRINTED POLYMERS AND ITS USE IN THE SELECTIVE EXTRACTION FOR DETERMINATION BROMHEXINE HYDROCHLORIDE AT PHARMACEUTICALS
}
A. R. Mahdi ${ }^{(1)}$
Researcher
Y. K. Al-Bayati ${ }^{(2)}$
Assist. Prof.
S. T. Ameen ${ }^{(1)}$
Prof.

Department of Chemistry, College of Science, University of Tikrit, IRAQ

Department of Chemistry, College of Science, University of Baghdad, IRAQ

Email: yahyaalbayti@yahoo.com

\section{ABSTRACT}

This study was aimed four electrodes were synthesized based on molecularly imprinted polymers (MIPs). Two MIPs were prepared by using bromhexine hydrochloride (BHH) as the template, acryl amide (AA) and methyl methacrylate (MMA) as monomers as well as ethylene glycol dimethacrylate (EGDMA) and penta erythritol triacrylate (PETA) as cross linkers respectively and benzoyl peroxide as initiator. The same composition was used in preparation of non-imprinted polymers (NIPs), but without the template (Bromhexine hydrochloride). To prepare the membranes, different plasticizers were used in PVC matrix such as: Di butyl sebacate (DBS), acetophenone (AP), di-octyl phthalate (DOPH) and tri-2-ethyl hexyl phosphate (TEHP). The characteristics studied are the slop, detection limit, life time and linearity range of $\mathrm{BHH}-\mathrm{MIPs}$ electrodes. Results obtained of selectivity measurements on interfering cations $\left(\mathrm{Al}^{+3}, \mathrm{Ca}^{+2}, \mathrm{~K}^{+}\right)$and some pharmaceutical additives such as methylparaben, propylparaben, trisodium citrate show that no interfering with drug bromhexine hydrochloride. The preparation electrodes have been shown good response including testing pharmaceutical analysis.

Keywords: Molecularly imprinted electrodes, bromhexine hydrochloride, potentiometric method, (MMA), (AA) monomers, different plasticizers.

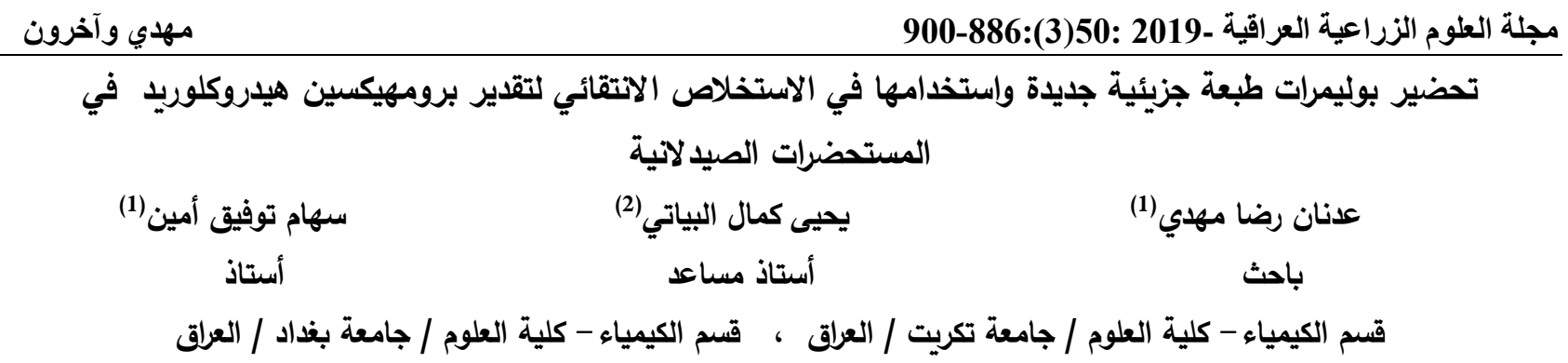

المستخلص

هدفت هذه الدراسة إلى تصنيع أربعة أقطاب بناءً على بوليميرات طبعة جزيئيًة (MIPs). تم تحضير اثثين من MIPs باستخدام

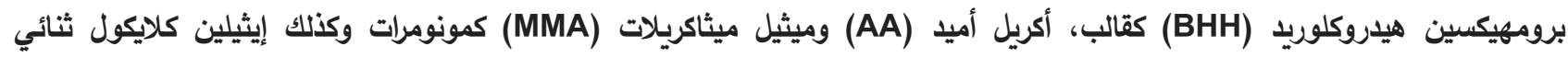

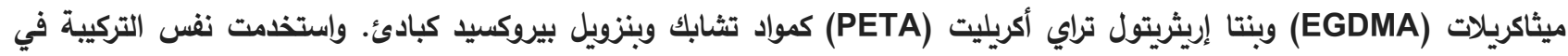
تحضير البوليمرات غير المطبوعة (NIPs) ، ولكن بدون القالب (Bromhexine hydrochloride). لتحضير الأغشية، تم استخدام مواد ملدنة مختلفة مع بولي فاينيل كلورايد كساند مثل: ثنائي بيوتيل سبكيت (DBS) ، الأسيتوفينون (AP) ، (DPS) ، ثنائي أوكتيل الفثالات وثلاثي إيثيل هكسيل الفوسفات (DOPH) الخطية لأقطاب BHH--MIPs. أظهرت النتائج التي تم الحصول عليها من قياسات الاتقائية على بعض الكاتيونات المسببة للتاخل )

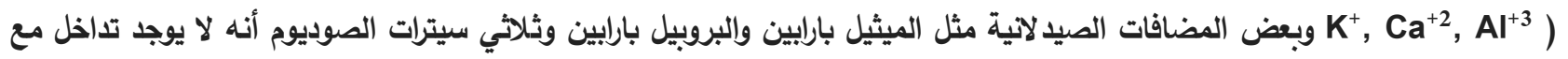
دواء برومهيكسين هيدروكلوريد. وقد أظهرت ألاقطاب المحضرة استجابة جيدة تضمنت اختبار التحليل الصيدلاتئي. الكلمات المفتاحية: أقطاب الطبعة الجزيئية، برومهيكسين هيدروكلورايد، طريقة جهدية، مونمرات (MMA) و (AA)، ملدنات مختلفة 


\section{INTRODUCTION}

Bromhexine hydrochloride [N-(2-Amino-3,5dibromobenzyl)-N-methylcyclohexanamine hydrochloride]. Bromhexine hydrochloride is a white or almost white, crystalline powder, very slightly soluble in water, slightly soluble in alcohol and in methylene chloride ${ }^{(17)}$. Bromhexine hydrochloride is a mucolytic agent that reduces sputum thickness, and works by breaking down mucus so it is easier to cough out. It helps patients breathe deeply, and is used to treat abnormal mucus secretions, including influenza, respiratory tract infections, and the common cold. In an overthe-counter form, bromhexine hydrochloride is used to treat cheat congestions and coughs ${ }^{(6)}$. Bromhexine hydrochloride's side effects include rash, diarrhea, vomiting, nausea, and pain in the upper stomach. This medication should not be used by pregnant or breastfeeding women. This medication should be avoided in patients with gastric ulcers due to the increased risk of adverse events ${ }^{(22)}$. The chemical formula of bromhexine hydrochloride is $\mathrm{C}_{14} \mathrm{H}_{20} \mathrm{Br}_{2} \mathrm{~N}_{2} . \mathrm{HCl}$, (M.Wt.:412.6 g. $\mathrm{mol}^{-1}$ ) and its structural formula show in Fig. 1.

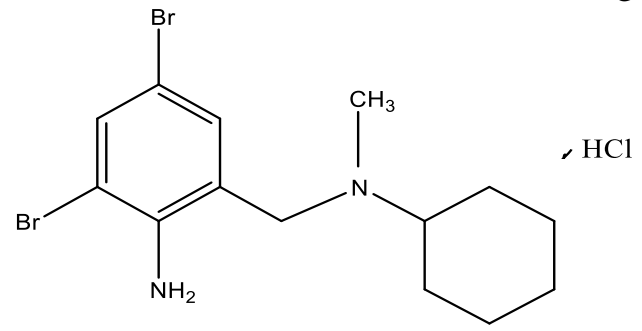

Fig. 1. Structure of Bromhexine hydrochloride According to review, bromhexine hydrochloride was determination by several methods such as these recent methods that employed reverse phase-high performance liquid chromatography ${ }^{(16,}$ 19) spectrophotometry $^{(14)}$, potentiometric-flow injection ${ }^{(11)}, \quad$ electrochemiluminescence system $^{(12)}$, TLC densitometric ${ }^{(18)}$. Several techniques used for determination drugs and pharmaceuticals. The selective electrodes technique one of these techniques that used for determination bromhexine hydrochloride because this technique has many characteristics like fast response time, easy used, rapid, low cost and selectivity. The potentiometric sensors techniques that is based on PVC membranes electrodes widely available used for analysis of drugs and ionic species $^{(9,21,7)}$. Molecularly imprinted polymers (MIPs) were used the bromhexine hydrochloride as the template while the monomers which used the acryl amide (AA) and methyl methacrylate (MMA) as monomers as well as ethylene glycol dimethacrylate (EGDMA) and penta erythritol triacrylate (PETA) as cross linkers respectively and benzoyl peroxide as initiator to achieved the polymerization process. There are a variety of ion selective electrode determined drugs that depended on MIPs as re cognition membranes like ibuprofen (1), warfarin (4), phenytoin (3) and metronidazole benzoate (2). In this study used different plasticizers to the construction of membranes electrodes based on BHH-MIPs such as di butyl sebacate (DBS), acetophenone (AP), dioctyl phthalate (DOPH) and tri-2-ethyl hexyl phosphate (TEHP).

\section{MATERIALS AND METHODS Preparation of MIP and NIP}

For preparation first bromhexine hydrochloride molecularly imprinted polymer (BHH-MIP1), $0.485 \mathrm{mmol}(0.20 \mathrm{~g})$ from bromhexine hydrochloride then mixed with $9.980 \mathrm{mmol}(1.00 \mathrm{~g})$ methyl methacrylate as the monomer, after that added $11.296 \mathrm{mmol}$ $(3.37 \mathrm{~g})$ penta erythritol triacrylate to the solution as the cross linker, followed that added $0.099 \mathrm{mmol}(0.02 \mathrm{~g})$ benzoyl peroxide as the initiator. All these materials were dissolved in $5 \pm \mathrm{mL}$ methanol $\left(\mathrm{CH}_{3} \mathrm{OH}\right)$. While the second bromhexine hydrochloride molecularly imprinted polymer (BHH-MIP2) were achieved by mixed $0.227 \mathrm{mmol}(0.09 \mathrm{~g})$ from bromhexine hydrochloride as the template, $1.500 \mathrm{mmol}(0.10 \mathrm{~g})$ acryl amide as the monomer, $15.00 \mathrm{mmol}(2.97 \mathrm{~g})$ ethylene glycol dimethacrylate as the cross linker and $0.099 \mathrm{mmol}(0.02 \mathrm{~g})$ benzoyl peroxide as the initiator which dissolved in $5 \pm \mathrm{mL}$ of methanol $\left(\mathrm{CH}_{3} \mathrm{OH}\right)$. For obtained a homogeneous solution, the mixture was stirred for 5 minutes. $\mathrm{N}_{2}$ passes for 30 minutes on the mixture to remove oxygen from solution. After that the solution was placed in a water bath at $60^{\circ} \mathrm{C}$. when the reaction completes the molecularly imprinted polymer became hardened, after the polymerization process the polymer was draying and crashed to obtain a polymer particle. These particles were sonicated in $\mathrm{CH}_{3} \mathrm{OH} / \mathrm{CH}_{3} \mathrm{COOH}(40: 4 \mathrm{v} / \mathrm{v})$ to remove the template from MIP. The particles size of BHH-MIP1 and BHH-MIP2 were between 43 - $60 \mu \mathrm{m}$ and $75-125 \mu \mathrm{m}$ respectively. The 
preparation of non-molecularly imprinted polymers using the same substances and conditions that formed BHH-MIP1 and BHHMIP2 but without the bromhexine hydrochloride (template). The same composition was used in preparation of nonimprinted polymers (NIPs), but without the template (Bromhexine hydrochloride).

\section{Instruments}

Ion analyzer used in this work (WTW model, Germany), a pH meter (WTW model pH 720, Germany), and a saturated calomel electrode (Gallenkamp, USA). The electrode BHH-MIP used was construction in the laboratory and all potentiometric measurements was made at room temperature. The bromhexine hydrochloride-MIP electrode combined with $\mathrm{Ag}-\mathrm{AgCl}$ electrode and the reference electrode was $0.1 \mathrm{M}$ internal solution of bromhexine hydrochloride. The PVC tube (1-4 cm long) was flattened and polished by putting it on a glass plate and soaking with THF. The membrane was cut similar to the external diameter of the PVC tubing and pasted on the polished end. The other direction of the PVC tubing was then linked to the electrode body. To make the electrodes more sensitive were by soaking in $0.1 \mathrm{M}$ bromhexine hydrochloride solution for at least (2-3 hours) before the use of the electrodes.

\section{Materials and chemicals}

1. Standard bromhexine hydrochloride obtained from industries of pharmaceuticals (IRAQ-SDI -Samara). Solvodin 20 tablets 8 $\mathrm{mg}$ from (SDI -Iraq), Bisolvon 20 tablets $8 \mathrm{mg}$ from (Boehringer Tngelheim- Germany), Mucolyte 20 tablets $8 \mathrm{mg}$ from (JulpharU.A.E.) were purchased from local pharmacies 2. Plasticizers, di butyl sebacate (DBS) $(97.0 \%$ purity), acetophenone (AP) (99.9\% purity), dioctyl phthalate (DOP) (99.5\% purity), Tri-2ethyl hexyl phosphate (TEHP) (97.0\% purity), were purchased from Sigma Aldrich. Other chemicals and reagents materials were obtained from Fluka, BDH and Sigma Aldrich

\section{Preparing of standard solutions}

1.For preparing standard solution of $0.1 \mathrm{M}$ bromhexine hydrochloride by dissolving 2.063 $\mathrm{g}$ of standard bromhexine hydrochloride in methanol and completed to $50 \mathrm{~mL}$ in the volumetric flask. The other solutions were prepared in $25 \mathrm{~mL}$ at the ranged from $10^{-6}-$ $10^{-1} \mathrm{M}$ in the same procedure

2. The stock standard solution of $1 \times 10^{-3} \mathrm{M}$, $1 \times 10^{-4} \mathrm{M}$, phospho molybdic acid was prepared by dissolving $0.225 \mathrm{~g}, \quad 0.022 \mathrm{~g}$ respectively in distilled water and completed to $100 \mathrm{~mL}$.

3. All interfering cations $\left(\mathrm{Al}^{+3}, \mathrm{Ca}^{+2}, \mathrm{~K}^{+}\right)$and some pharmaceutical additives such as methylparaben, propylparaben, trisodium citrate $0.1 \mathrm{M}$ stock solution prepared at ranged from $10^{-6}-10^{-1} \mathrm{M}$ which present the interfering ions were prepared and diluted to $100 \mathrm{~mL}$.

Synthesis of membrane molecularly imprinted polymers electrode

Bromhexine hydrochloride membrane was immobilized into the PVC tube as portrayed by Thomas and Moody ${ }^{(15)}$. BHH-MIP of $0.036 \mathrm{~g}$ was mixed with different of plasticizers $0.4 \mathrm{~g}$ used in this work such as: DBS (electrode A1), AP (electrode A2), DOPH (electrode B1) and TEHP (electrode B2). Then added $0.17 \mathrm{~g}$ of PVC powder was scattered on $7 \pm \mathrm{mL}$ of tetra hydro furan with stirring until a clear viscous solution was acquired. Then the solutions mixed with stirring until the mixture became homogeneous. The mixture was casted into a glass ring $30-35 \mathrm{~mm}$ diameter and unwind on a glass plate and a ribbon of filter was placed on top of the glass. The solvent was then allowed to evaporate according to room temperature more than 24-48 hours at least. The thickness of the membrane obtained was different of membrane to other's, the thickness was about $0.4-0.7 \mathrm{~mm}$. That size of membrane was adequate to prepare electrodes.

\section{Scanning electron microscope SEM}

In scanning electron microscopy, a fine beam of electrons scans the membrane surface. This causes several kinds of interactions generating different signals, also used in image formation. The SEM can be used to get an idea about the size, geometry, and distribution of pore surface of the membranes. SEM analysis showed the highly ordered and regular pore structure of the molecular imprinted polymer surface and the cross-section. Several papers showed that the molecular imprinted membranes recognized the template molecule effectively and transported it with good efficiency due to porous structures of the molecular imprinted 
polymer. The ordered porous and cross section on surface shows the sites of interaction, and MIP showed the highest transport rate towered the template molecule. The morphology of MIP before and after washing showed by electron microscope in Figure $(2 \mathrm{a}, 2 \mathrm{~b})$ and

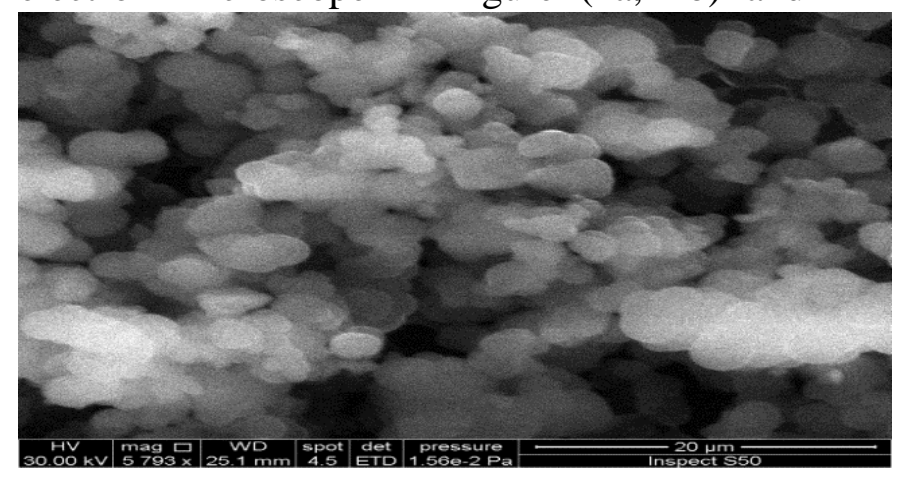

Fig. 2a. SEM for the MIP1 before washing

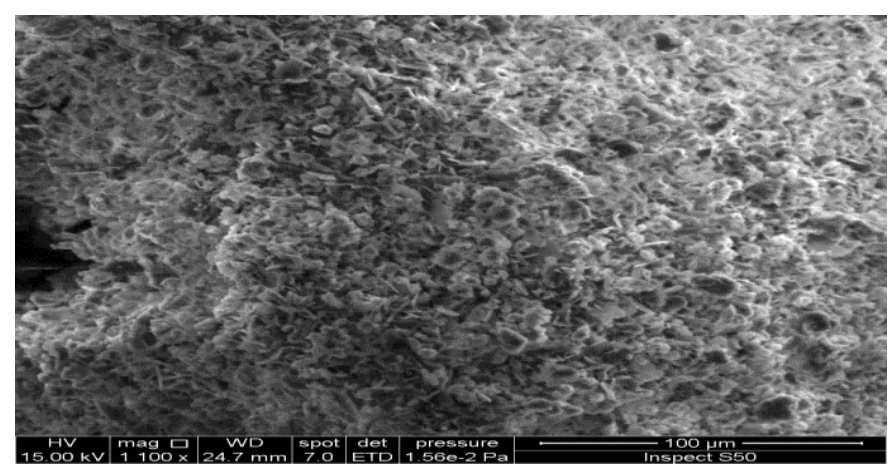

Fig. 3a. SEM for the MIP2 before washing

The morphology of the prepared membrane using the BHH-MIP1 before washing is shown in figure $2 \mathrm{a}$ and after washing is shown in figure $2 b$. Figure $2 a$ (before washing) reveals that the particles of the complex are formed in a regular spherical shape with an average of about $200 \mu \mathrm{m}$ in diameter. In other hand, figure $2 b$ (after washing) shows that the formed particles look like a colloidal particle growing in a solution, this might take place due to a presence of excess of DFS that form ionic atmosphere surrounding the complex and create the formation of electric double layers.

Construction of ion-selective electrodes

The building of the electrode body and the immobilization were achieved as portrayed by Mahajan et al $\left.{ }^{(13}\right)$. Bromhexine hydrochloride solution (0.1) M was filled in the glass tube as an internal solution. Preferred immersing the membrane in standard solution of (0.1) $\mathrm{M}$ of bromhexine hydrochloride for at least (2-3)
Figure (3a, 3b). Micro emulsion polymerization gives very small particles size around (600-850) nm for methyl methacrylate (MMA) polymer and (400-1,000) nm for acryl amide (AA) polymer can be distinguished in the related image.

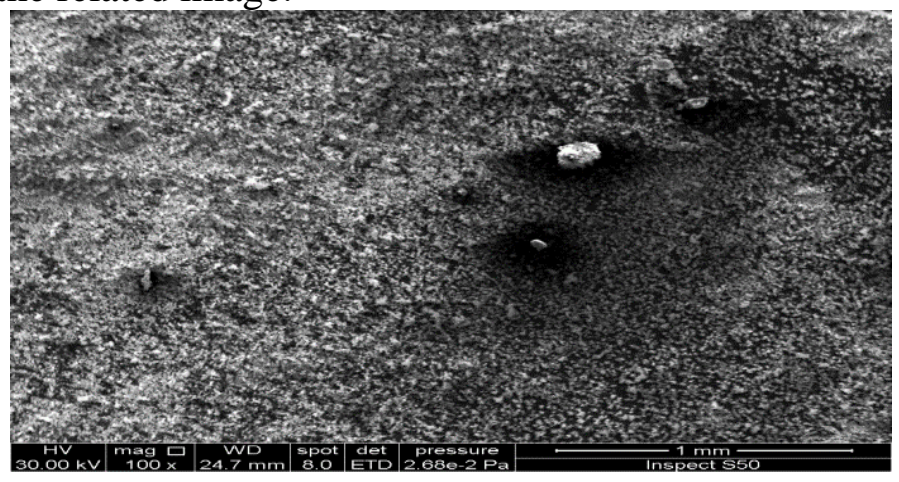

Fig.2b. shows the SEM for MIP1after washing

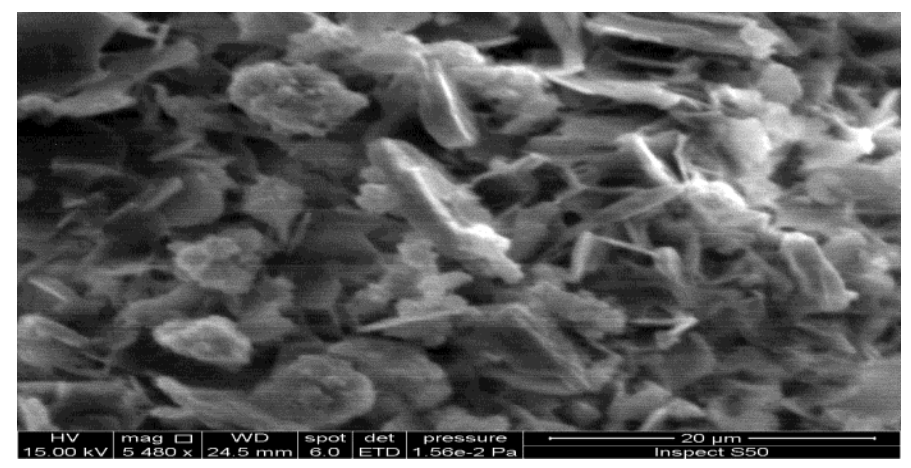

Fig.3b. shows the SEM for MIP2 after washing

hours before measurements which represents stipulations of membrane electrode

Preparation of pharmaceutical samples

To obtained the powder of tablets pharmaceutical samples using pestle and mortar to grinding the tablets then taken a suitable weight for preparation in $50 \mathrm{~mL}$ of solutions .Used appropriate amount of methanol $\left(\mathrm{CH}_{3} \mathrm{OH}\right)$ for dissolved pharmaceutical samples and complete to 50 $\mathrm{mL}$ in the volumetric flask by methanol as well as using the magnetic stirrer for more than 30 minutes .After that filtered the solution by using $0.07 \mu \mathrm{m}$ cellulose filter paper for preparing and obtained the concentrations of 1 $\mathrm{x} 10^{-3} \mathrm{M}$ and $1 \times 10^{-4} \mathrm{M}$ bromhexine hydrochloride.

\section{RESULTS AND DISCUSSION}

Ion-selective electrodes (ISE) is one of the sensors that considered most common which used voltage through measurements. Used this measurement in the laboratory tests, industry, 
process control, physiological measurements, and environmental monitoring. (5) Electrodes membranes that responded to the concentration analysis using a chemical reaction to generate ions that can be monitored with ion selective electrode ${ }^{(20)}$. These membrane electrodes included two main categories are ions selective electrodes which be sensitive to ionic species and molecular selective electrodes that applied to determination of molecular analytes ${ }^{(8,15)}$. The principle working of ion-selective electrodes consist of two different types of electrical conductivity which are in metals the electric current is carried by electrons while in Liquids the electric current is carried by ions ${ }^{(13)}$. The measurement of conductivity for each electrochemical process can be achieved in one of this type galvanic cell, electrolysis and electrical analysis. This type of cells must be contact with the solution on both sides of the cell membrane also there is some ISE arrangements with wire connection to one side of the membrane. Traditional composition of the cell is:

Outer ref. / Test solution / membrane/ internal ref.

Or

Outer ref. / Test solution / ion-selective electrode

The current which passed through the electrolytical cell must be equals zero depending on this condition the cell is designed according to the basic rule of designing of electrolytic cells.

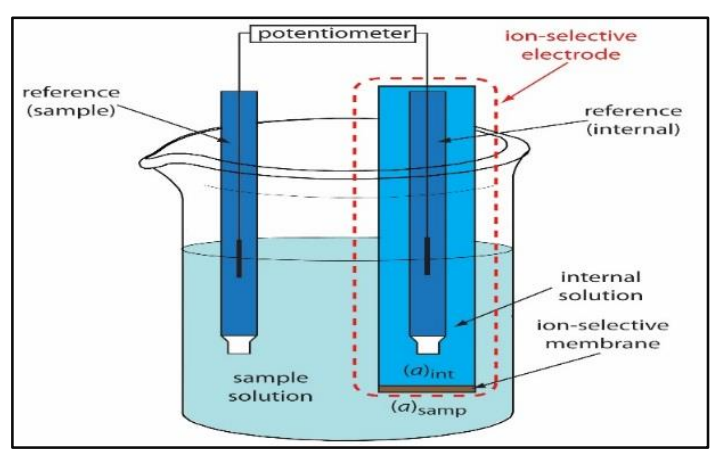

Fig. 4. Schematic diagram showing a typical potentiometric cell with an ion-selective electrode

Two MIPs have been prepared by using the bromhexine hydrochloride as the template, acryl amide (AA) and methyl methacrylate (MMA) as monomers as well as ethylene glycol dimethacrylate (EGDMA) and penta erythritol triacrylate (PETA) as cross linkers respectively and benzoyl peroxide as initiator. A plasticizer is an important component in an ISE membrane. Compatibility with the polymer and other membrane constituents provides a homogeneous environment for membrane when the plasticizers using as a solvent for the membrane practical use of ISE membrane should be avoided leaching of the plasticizer, otherwise it would affect the electrode performance over time. Four electrodes have been construct based on PVC matrix. These plasticizers such as: di butyl sebacate (DBS), acetophenone (AP), di-octyl phthalate (DOP), Tri-2- ethyl hexyl phosphate (TEHP). The characteristics was studied for all electrodes based on BHH-MIP1 (A1, A2 membranes) and BHH-MIP2 (B1, B2 membranes) which included linearity range, correlation coefficients, detection limit (M) and life time (day) respectively. The results obtained showed in the table 1 and figure 5.

Table 1. Characteristics of the bromhexine hydrochloride-MIP electrode based on different functional monomers and plasticizers

\begin{tabular}{|c|c|c|c|c|}
\hline Membrane composition & $\begin{array}{l}\text { BHH-MIP1 } \\
+ \text { DBS (A1) }\end{array}$ & $\begin{array}{c}\text { BHHMIP1 } \\
+\mathrm{ACPH} \mathrm{(A2)}\end{array}$ & $\begin{array}{c}\text { BHH-MIP2 } \\
+ \text { DOPH (B1) }\end{array}$ & $\begin{array}{r}\text { ВНH-MIP2 } \\
+ \text { TEHP (B2) }\end{array}$ \\
\hline Slop (mV/decade) & -18.02 & -20.45 & -19.47 & -17.00 \\
\hline Linearity range (M) & $5 \times 10^{-5}-1 \times 10^{-1}$ & $5 \times 10^{-5}-1 \times 10^{-1}$ & $5 \times 10^{-5}-1 \times 10^{-1}$ & $5 \times 10^{-5}-1 \times 10^{-1}$ \\
\hline Correlation coefficient & 0.9998 & 0.9998 & 0.9932 & 0.9995 \\
\hline Detection limit (M) & $2.6 \times 10^{-5}$ & $1.8 \times 10^{-5}$ & $9.2 \times 10^{-6}$ & $9 \times 10^{-6}$ \\
\hline Life time (day) & 14 & 9 & 19 & 8 \\
\hline
\end{tabular}




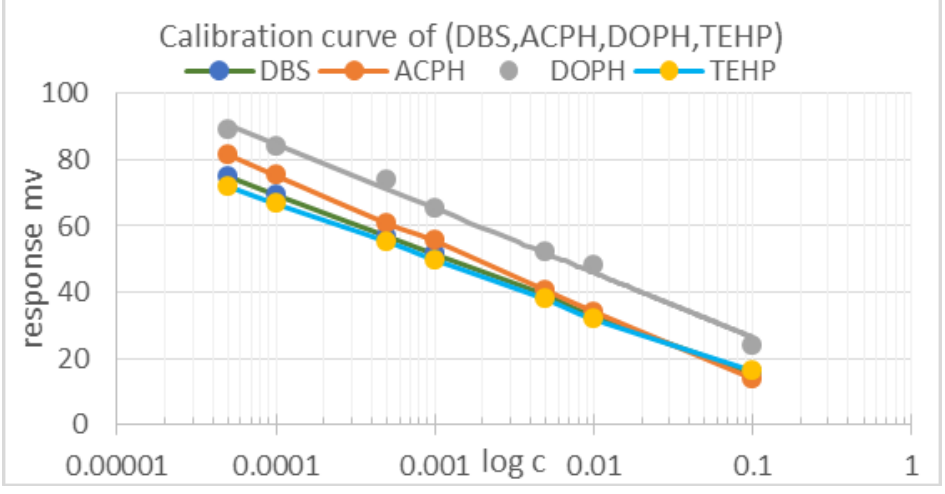

Fig. 5. Calibration curve for BHH-MIP1 and BHH-MIP2 membranes electrodes

Effect of pH on electrodes response

The study of $\mathrm{pH}$ effected on $\mathrm{BHH}-\mathrm{HCl}$ membranes electrodes by prepared various concentrations of $\mathrm{BHH}-\mathrm{HCl}\left(1 \times 10^{-2}, 1 \times 10^{-3}\right.$ and $\left(\times 10^{-4}\right) \mathrm{M}$. To measurement the selective $\mathrm{pH}$ at ranged (1-11) by using the hydrochloric acid $(0.1 \mathrm{M}, 1 \mathrm{M})$ and/or sodium hydroxide
$(0.1 \mathrm{M}, 1 \mathrm{M})$ for $\mathrm{pH}$ studies. The results obtained by adding appropriate volume of $\mathrm{HCl} / \mathrm{NaOH}$ as shows in the Table (2) and Fig. $(6,7)$. The change in potentials at differential $\mathrm{pH}$ values my be due to the composition of electrodes. This composition also effects on response and life time for electrodes.

Table 2. Working pH range for Bromhexine Hydrochloride Selective electrode

\begin{tabular}{|c|c|c|c|c|c|}
\hline \multirow{2}{*}{$\begin{array}{c}\text { Number and } \\
\text { composition of MIPs }\end{array}$} & \multirow[t]{2}{*}{ Membranes } & \multirow{2}{*}{$\begin{array}{l}\text { Membrane } \\
\text { composition }\end{array}$} & \multicolumn{3}{|c|}{ pH range } \\
\hline & & & $1 \times 10^{-2} M$ & $1 \times 10^{-3} \mathrm{M}$ & $1 \times 10^{-4} \mathrm{M}$ \\
\hline MIP1 & A1 & BHH-MIP1 +DBS & $3.5-8.5$ & 3.0-8.5 & $3.0-8.5$ \\
\hline ВНН+ММА+РЕНР & A2 & ВНH-MIP1 +ACPH & $3.5-8.0$ & 4.0-8.5 & $3.5-8.5$ \\
\hline MIP2 & B1 & ВHH-MIP2+DOPH & 2.5-9.5 & $3.5-9.0$ & $3.0-9.5$ \\
\hline BHH+ AA +EGDMA & B2 & BHH-MIP2 + TEHP & 3.5-8.0 & 4.0-7.5 & 4.0-7.5 \\
\hline
\end{tabular}
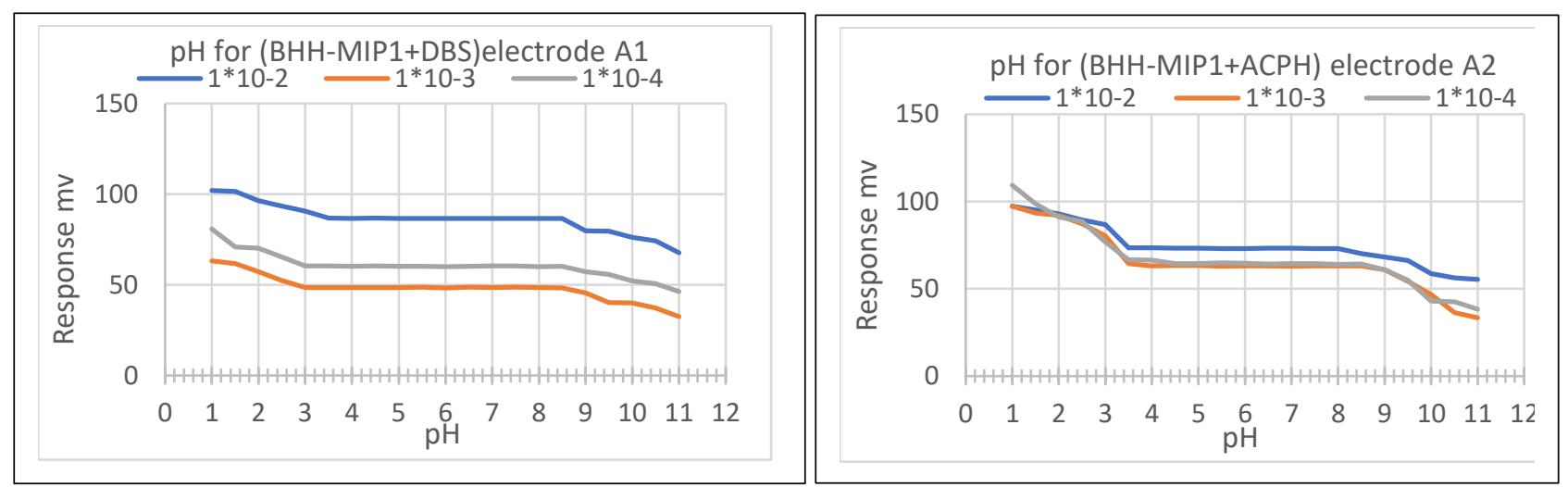

Fig. 6. Effect of pH on the Bromhexine Hydrochloride \{BHH-MIP1 + DBS (A1) and BHHMIP1 + ACPH (A2) $\}$ electrodes at concentration $1 \times 10^{-2}, 1 \times 10^{-3}$ and $1 \times 10^{-4} \mathrm{M}$
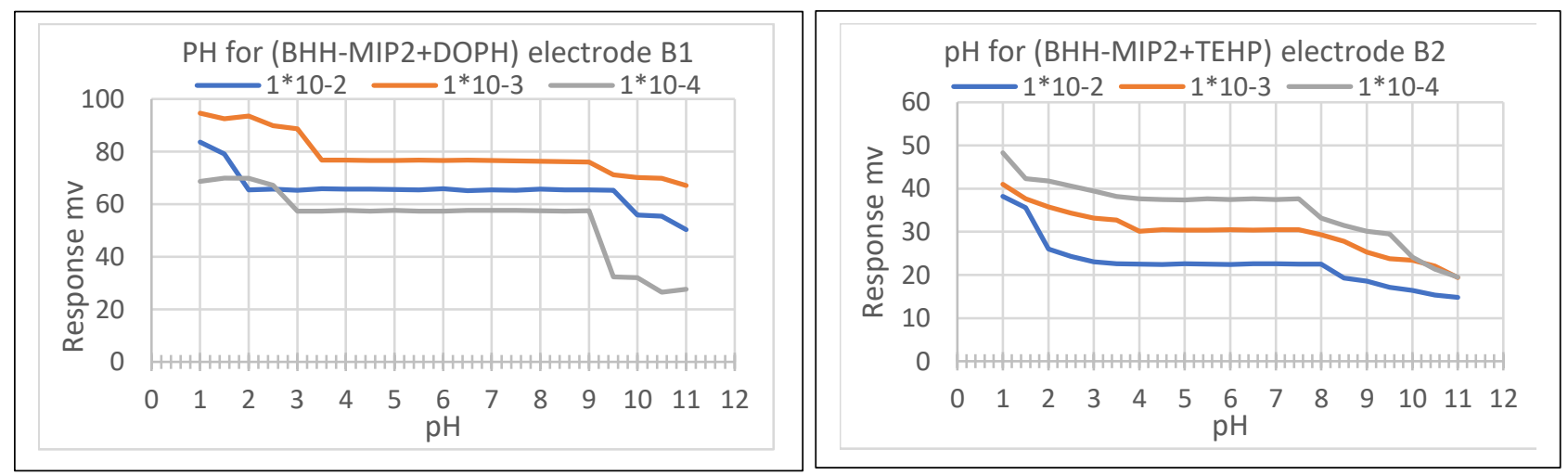

Fig.7. Effect of pH on the Bromhexine Hydrochloride \{BHH-MIP2 + DOPH (B1) and BHH-MIP2 + TEHP (B2) $\}$ electrodes at concentration $1 \times 10^{-2}, 1 \times 10^{-3}$ and $1 \times 10^{-4} \mathrm{M}$. 


\section{Interference studies}

For calculated the selectivity coefficient measurement was used the separate solution method. Used the separate equation for these measurements according to the equation below.

Log K pot $=[($ EB - EA $) /(2.303 R T / z$ F $)]+(1$ $-\mathbf{z A} / \mathbf{z B}) \log \mathbf{A a}$

EA, EB; zA, zB; and aA, represents the potentials, charge numbers, and activities for the primary $\mathrm{A}$ and interfering $\mathrm{B}$ ions, respectively at $\mathrm{aA}=\mathrm{aB}, \mathrm{R}$, the ideal gas constant $\left(3.314\right.$ joule mole $\left.\mathrm{K}^{-1}\right), \mathrm{K}^{\text {pot }}$, selectivity coefficient. The results obtained for selectivity coefficients of primary ion and interfering ions like cations and some pharmaceutical additives used in this work. The selectivity coefficients depend on charges of both primary ion and interfering ions also depends on concentration as well as the composition of electrodes. All values for selectivity coefficients were listed in the table $3,4,5,6$ and figures $(8,9)$.

Table 3. Selectivity coefficients for (BHH -MIP1 +DBS) electrode at different concentrations of bromhexine hydrochloride

\begin{tabular}{|c|c|c|c|c|c|c|c|c|c|c|c|c|c|c|}
\hline \multirow{3}{*}{$\begin{array}{l}\text { Interfer } \\
\text { ing ions }\end{array}$} & \multicolumn{14}{|c|}{ Concentrations of Bromhexine. $\mathrm{HCl}(\mathrm{M})$ : Concentration of interference ions (M) } \\
\hline & \multicolumn{2}{|c|}{$10^{-1}$} & \multicolumn{2}{|c|}{$10^{-2}$} & \multicolumn{2}{|c|}{$5 \times 10^{-3}$} & \multicolumn{2}{|c|}{$1 \times 10^{-3}$} & \multicolumn{2}{|c|}{$5 \times 10^{-4}$} & \multicolumn{2}{|c|}{$1 \times 10^{-4}$} & \multicolumn{2}{|c|}{$5 \times 10^{-5}$} \\
\hline & $\begin{array}{c}\mathbf{E}_{\mathrm{B}} \\
(\mathbf{m v})\end{array}$ & $\mathbf{K}_{\mathrm{A}, \mathbf{B}}$ & $\begin{array}{c}\mathbf{E}_{\mathrm{B}} \\
(\mathbf{m v})\end{array}$ & $\mathbf{K}_{\mathrm{A}, \mathbf{B}}$ & $\underset{(\mathbf{m v})}{\mathbf{E}_{\mathbf{B}}}$ & $\mathbf{K}_{\mathrm{A}, \mathbf{B}}$ & $\underset{(\mathbf{m v})}{\mathbf{E}_{\mathbf{B}}}$ & $\mathbf{K}_{\mathrm{A}, \mathbf{B}}$ & $\underset{(\mathbf{m v})}{\mathbf{E}_{\mathrm{B}}}$ & $\mathbf{K}_{\mathrm{A}, \mathbf{B}}$ & $\underset{(\mathbf{m v})}{\mathbf{E}_{\mathrm{B}}}$ & $\mathbf{K}_{\mathrm{A}, \mathbf{B}}$ & $\underset{(\mathbf{m v})}{\mathbf{E}_{\mathrm{B}}}$ & $\mathbf{K}_{\mathrm{A}, \mathbf{B}}$ \\
\hline $\mathbf{K}^{+}$ & 18.3 & 0.6393 & 33.8 & 0.6024 & 42.5 & 0.3712 & 53.8 & 0.5759 & 62.4 & 0.3589 & 71.3 & 0.5824 & 65.5 & 0.6162 \\
\hline $\mathrm{Ca}^{+2}$ & 19.2 & 0.1896 & 37.1 & 0.4864 & 39.8 & 0.5824 & 50.3 & 0.7378 & 57.6 & 0.5263 & 72.3 & 0.6519 & 71.9 & 0.3840 \\
\hline $\mathbf{A l}^{+3}$ & 17.3 & 0.1377 & 33.6 & 0.5088 & 49.0 & 0.1458 & 59.7 & 0.2313 & 62.4 & 0.2708 & 70.8 & 0.4975 & 80.6 & 0.1017 \\
\hline T.S. C & 19.2 & 0.0727 & 34.6 & 0.1075 & 44.8 & 0.1746 & 56.2 & 0.3280 & 65.3 & 0.2739 & 72.3 & 0.2589 & 71.5 & 0.0950 \\
\hline M. P. & 19.5 & 0.5555 & 38.7 & 0.3840 & 44.2 & 0.4017 & 58.6 & 0.4062 & 62.3 & 0.3712 & 75.9 & 0.3431 & 75.3 & 0.3589 \\
\hline P. P. & 23.6 & 0.3375 & 49.1 & 0.1075 & 46.8 & 0.1746 & 54.2 & 0.3280 & 60.8 & 0.2739 & 70.6 & 0.2589 & 74.3 & 0.0950 \\
\hline
\end{tabular}

Table 4. Selectivity coefficients for (BHH -MIP1 +ACPH) electrode at different concentrations of bromhexine hydrochloride

\begin{tabular}{|c|c|c|c|c|c|c|c|c|c|c|c|c|c|c|}
\hline \multirow{3}{*}{$\begin{array}{l}\text { Interfering } \\
\text { ions }\end{array}$} & \multicolumn{14}{|c|}{ Concentrations of Bromhexine. $\mathrm{HCl}(\mathrm{M})$ : Concentration of interference ions (M) } \\
\hline & \multicolumn{2}{|c|}{$10^{-1}$} & \multicolumn{2}{|c|}{$10^{-2}$} & \multicolumn{2}{|c|}{$5 \times 10^{-3}$} & \multicolumn{2}{|c|}{$1 \times 10^{-3}$} & \multicolumn{2}{|c|}{$5 \times 10^{-4}$} & \multicolumn{2}{|c|}{$1 \times 10^{-4}$} & \multicolumn{2}{|c|}{$5 \times 10^{-5}$} \\
\hline & $\underset{(\mathbf{m v})}{\mathbf{E}_{\mathbf{B}}}$ & $\mathbf{K}_{\mathbf{A}, \mathbf{B}}$ & $\underset{(\mathbf{m v})}{\mathbf{E}_{\mathbf{B}}}$ & $\mathbf{K}_{\mathbf{A}, \mathbf{B}}$ & $\underset{(\mathbf{m v})}{\mathbf{E}_{\mathbf{B}}}$ & $\mathbf{K}_{\mathbf{A}, \mathbf{B}}$ & $\underset{(\mathbf{m v})}{\mathbf{E}_{\mathbf{B}}}$ & $\mathbf{K}_{\mathbf{A}, \mathbf{B}}$ & $\underset{(\mathbf{m v})}{\mathbf{E}_{B}}$ & $\mathbf{K}_{\mathbf{A}, \mathbf{B}}$ & $\underset{(\mathbf{m v})}{\mathbf{E}_{\mathbf{B}}}$ & $\mathbf{K}_{\mathbf{A}, \mathbf{B}}$ & $\underset{(\mathbf{m v})}{\mathbf{E}_{\mathbf{B}}}$ & $\mathbf{K}_{\mathbf{A}, \mathbf{B}}$ \\
\hline $\mathbf{K}^{+}$ & 21.6 & 0.2211 & 33.8 & 0.4598 & 45.7 & 0.3431 & 67.2 & 0.4249 & 73.9 & 0.5505 & 79.6 & 0.4249 & 82.3 & 0.2589 \\
\hline $\mathrm{Ca}^{+2}$ & 24.3 & 0.1374 & 43.8 & 0.01746 & 52.3 & 0.0097 & 62.8 & 0.0040 & 64.4 & 0.0120 & 86.2 & 0.0006 & 87.1 & 0.0017 \\
\hline $\mathbf{A l}^{+3}$ & 44.6 & 0.0476 & 47.2 & 0.0082 & 49.0 & 0.0073 & 58.9 & 0.0023 & 67.3 & 0.0020 & 77.3 & 0.0005 & 80.6 & 0.0001 \\
\hline T.S. C & 49.2 & 0.1096 & 54.8 & 0.0161 & 59.8 & 0.0122 & 67.6 & 0.0023 & 72.3 & 0.0021 & 79.3 & 0.0012 & 84.6 & 0.0006 \\
\hline M. P. & 47.9 & 0.1595 & 52.6 & 0.2067 & 59 & 0.1806 & 65.3 & 0.1362 & 69.8 & 0.1347 & 74.1 & 0.1458 & 82.3 & 0.1393 \\
\hline P. P. & 47.2 & 0.5146 & 54.3 & 0.2997 & 60.2 & 0.2801 & 69.2 & 0.1560 & 72.0 & 0.2531 & 76.0 & 0.2678 & 79.3 & 0.2801 \\
\hline
\end{tabular}

Table 5. Selectivity coefficients for (BHH -MIP2 +DOPH) electrode at different concentrations of bromhexine hydrochloride

\begin{tabular}{|c|c|c|c|c|c|c|c|c|c|c|c|c|c|c|}
\hline \multirow{3}{*}{$\begin{array}{l}\text { Interfering } \\
\text { ions }\end{array}$} & \multicolumn{14}{|c|}{ Concentrations of Bromhexine. $\mathrm{HCl}(\mathrm{M})$ : Concentration of interference ions (M) } \\
\hline & \multicolumn{2}{|c|}{$10^{-1}$} & \multicolumn{2}{|c|}{$10^{-2}$} & \multicolumn{2}{|c|}{$5 \times 10^{-3}$} & \multicolumn{2}{|c|}{$1 \times 10^{-3}$} & \multicolumn{2}{|c|}{$5 \times 10^{-4}$} & \multicolumn{2}{|c|}{$1 \times 10^{-4}$} & \multicolumn{2}{|c|}{$5 \times 10^{-5}$} \\
\hline & $\underset{(\mathbf{m v})}{\mathbf{E}_{\mathbf{B}}}$ & $\mathbf{K}_{\mathbf{A}, \mathbf{B}}$ & $\underset{(\mathbf{m v})}{\mathbf{E}_{\mathbf{B}}}$ & $\mathbf{K}_{\mathbf{A}, \mathbf{B}}$ & $\underset{(\mathbf{m v})}{\mathbf{E}_{\mathbf{B}}}$ & $\mathbf{K}_{\mathbf{A}, \mathbf{B}}$ & $\begin{array}{c}\mathbf{E}_{B} \\
(\mathbf{m v})\end{array}$ & $\mathbf{K}_{\mathbf{A}, \mathbf{B}}$ & $\underset{(\mathbf{m v})}{\mathbf{E}_{\mathbf{B}}}$ & $\mathbf{K}_{\mathrm{A}, \mathbf{B}}$ & $\underset{(\mathbf{m v})}{\mathbf{E}_{\mathbf{B}}}$ & $\mathbf{K}_{\mathrm{A}, \mathbf{B}}$ & $\underset{(\mathbf{m v})}{\mathbf{E}_{\mathbf{B}}}$ & $\mathbf{K}_{\mathbf{A}, \mathbf{B}}$ \\
\hline $\mathbf{K}^{+}$ & 35.7 & 0.0204 & 40.3 & 0.0592 & 49.3 & 0.3431 & 67.2 & 0.4249 & 73.9 & 0.5505 & 79.6 & 0.4249 & 92.3 & 0.2589 \\
\hline $\mathrm{Ca}^{+2}$ & 75.3 & 0.0334 & 79.9 & 0.0066 & 84.6 & 0.0050 & 88.1 & 0.0021 & 92.8 & 0.0014 & 100.6 & 0.0002 & 102.7 & 0.0003 \\
\hline $\mathbf{A l}^{+3}$ & 64.7 & 0.0068 & 69.7 & 0.0012 & 78.6 & 0.0004 & 84.6 & 0.0001 & 98.7 & 0.0002 & 104.3 & 0.0006 & 112.3 & 0.0001 \\
\hline T.S. C & 46.1 & 0.0150 & 53.6 & 0.0059 & 68.9 & 0.0009 & 72.4 & 0.0004 & 88.3 & 0.0004 & 97.4 & 0.0001 & 105.6 & $5 \times 10^{-6}$ \\
\hline M. P. & 75.0 & 0.0298 & 79.3 & 0.0235 & 84.3 & 0.0143 & 88.2 & 0.0111 & 91.3 & 0.0131 & 97.6 & 0.0148 & 105.7 & 0.0104 \\
\hline P.P. & 42.0 & $\mathbf{0 . 0 2 3 5}$ & 49.7 & 0.0513 & 58.2 & 0.0961 & 64.7 & 0.1247 & 78.9 & 0.0445 & 88.3 & 0.0715 & 98.7 & 0.0415 \\
\hline
\end{tabular}


Table 6. Selectivity coefficients for (BHH -MIP2 + TEHP) electrode at different concentrations of bromhexine hydrochloride

\begin{tabular}{|c|c|c|c|c|c|c|c|c|c|c|c|c|c|c|}
\hline \multirow{3}{*}{$\begin{array}{l}\text { Interfering } \\
\text { ions }\end{array}$} & \multicolumn{14}{|c|}{ Concentrations of Bromhexine. $\mathrm{HCl}(\mathrm{M})$ : Concentration of interference ions (M) } \\
\hline & \multicolumn{2}{|c|}{$10^{-1}$} & \multicolumn{2}{|c|}{$10^{-2}$} & \multicolumn{2}{|c|}{$5 \times 10^{-3}$} & \multicolumn{2}{|c|}{$1 \times 10^{-3}$} & \multicolumn{2}{|c|}{$5 \times 10^{-4}$} & \multicolumn{2}{|c|}{$1 \times 10^{-4}$} & \multicolumn{2}{|c|}{$5 \times 10^{-5}$} \\
\hline & $\underset{(\mathbf{m v})}{\mathbf{E}_{\mathbf{B}}}$ & $\mathbf{K}_{\mathbf{A}, \mathbf{B}}$ & $\begin{array}{c}\mathbf{E}_{\mathbf{B}} \\
(\mathbf{m v v})\end{array}$ & $\mathbf{K}_{\mathbf{A}, \mathbf{B}}$ & $\begin{array}{c}\mathbf{E}_{\mathbf{B}} \\
(\mathbf{m v})\end{array}$ & $\mathbf{K}_{\mathbf{A}, \mathbf{B}}$ & $\begin{array}{c}\mathbf{E}_{\mathbf{B}} \\
(\mathbf{m v})\end{array}$ & $\mathbf{K}_{\mathbf{A}, \mathbf{B}}$ & $\begin{array}{c}\mathbf{E}_{\mathbf{B}} \\
(\mathbf{m v})\end{array}$ & $\mathbf{K}_{\mathbf{A}, \mathbf{B}}$ & $\begin{array}{c}\mathbf{E}_{\mathbf{B}} \\
(\mathbf{m v})\end{array}$ & $\mathbf{K}_{\mathbf{A}, \mathbf{B}}$ & $\begin{array}{c}\mathbf{E}_{\mathbf{B}} \\
(\mathbf{m v})\end{array}$ & $\mathbf{K}_{\mathbf{A}, \mathbf{B}}$ \\
\hline $\mathbf{K}^{+}$ & 62.3 & 0.0388 & 68.7 & 0.0367 & 72.5 & 0.0559 & 76.2 & 0.0733 & 79.5 & 0.0649 & 83.4 & 0.0530 & 87.9 & 0.0817 \\
\hline $\mathbf{C a}^{+2}$ & 49.8 & 0.0450 & 58.6 & 0.0303 & 69.2 & 0.0051 & 74.3 & 0.0041 & 75.1 & 0.0034 & 81.8 & 0.0010 & 92.5 & 0.0004 \\
\hline $\mathbf{A l}^{+3}$ & 71.7 & 0.0014 & 82.3 & 0.0003 & 88.9 & 0.0001 & 110.3 & $7 \times 10^{-6}$ & 112.8 & $8 \times 10^{-6}$ & 121.8 & $1.3 \times 10^{-6}$ & 131.2 & $3.5 \times 10^{-7}$ \\
\hline T.S. C & 96.3 & $3.3 \times 10^{-5}$ & 97.9 & $1.5 \times 10^{-5}$ & 88.9 & $9.0 \times 10^{-5}$ & 92.4 & $6.8 \times 10^{-5}$ & 102.8 & $2.4 \times 10^{-5}$ & 124.6 & $6.6 \times 10^{-7}$ & 130.8 & $3.5 \times 10^{-7}$ \\
\hline M. P. & 44.6 & 0.2446 & 49.3 & 0.2195 & 55.9 & 0.1586 & 58.6 & 0.1943 & 60.9 & 0.2480 & 65.3 & 0.2618 & 74.8 & 0.2225 \\
\hline P.P. & 44.7 & 0.2917 & 50.2 & 0.4879 & 58.8 & 0.2917 & 59.9 & 0.4879 & 64.8 & 0.5013 & 70.1 & 0.6142 & 76.8 & 0.4379 \\
\hline
\end{tabular}
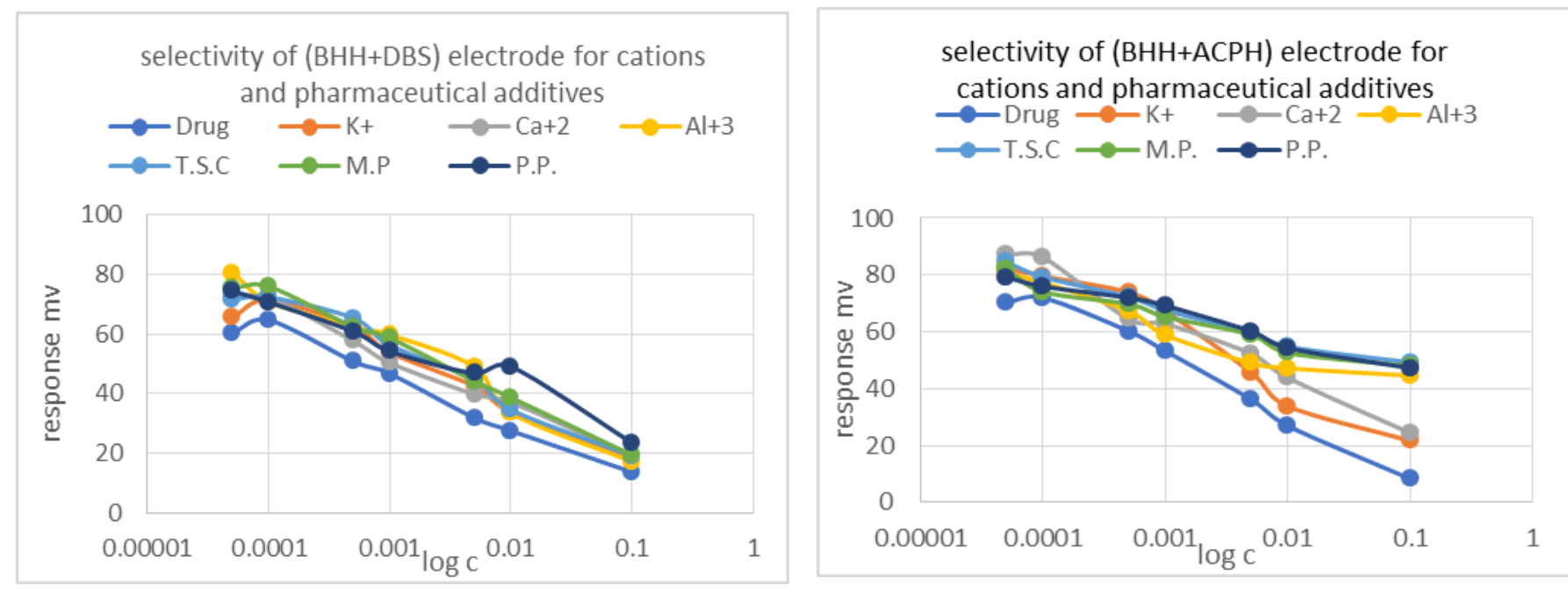

Fig. 8. Selectivity of (BHH-MIP 1 + DBS and BHH-MIP 1 + ACPH) electrodes with cations $\left(\mathrm{K}^{+}, \mathrm{Ca}^{+2}, \mathrm{Al}^{+3}\right)$ and some pharmaceutical additives (T.S.C, M.P, P.P) via Separation Solution Method
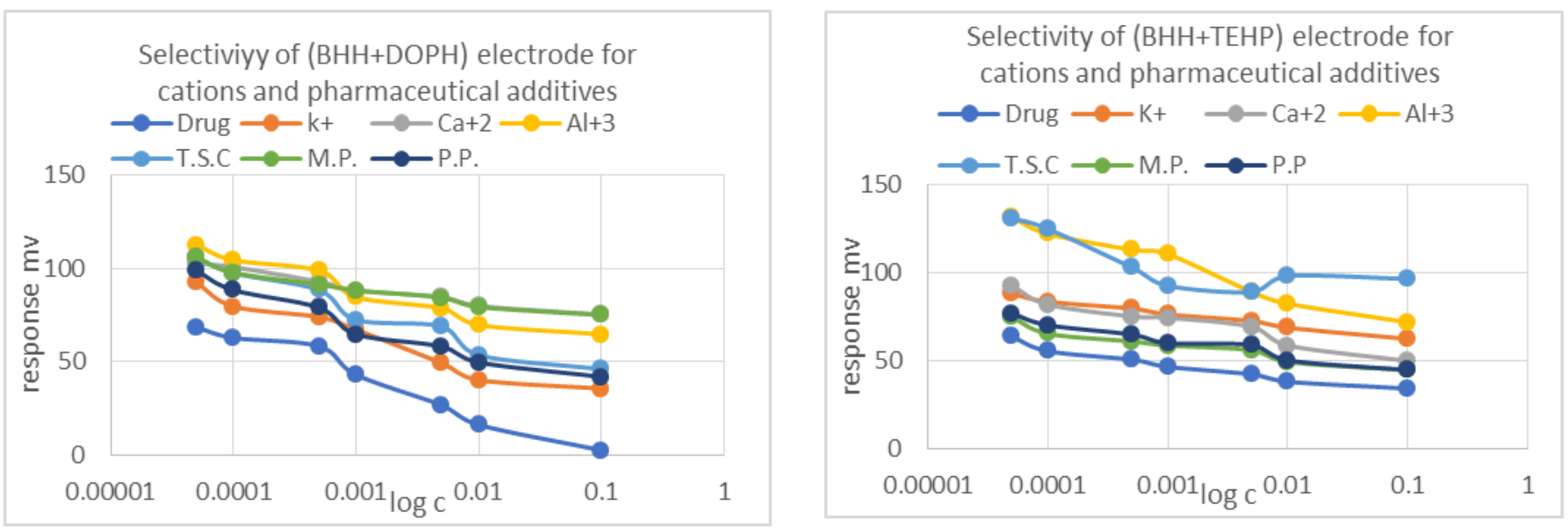

Fig. 9. Selectivity of (BHH-MIP $2+$ DOPH and BHH-MIP $2+$ TEHP) electrodes with cations $\left(\mathrm{K}^{+}, \mathrm{Ca}^{+2}, \mathrm{Al}^{+3}\right)$ and some pharmaceutical additives (T.S.C, M.P, P.P) via Separation Solution Method

Calculation by Multiple Standard Addition Method (MSA)

The concentrations used for applied in this method $\left(1 \times 10^{-3} \& 1 \times 10^{-4}\right)$ for two solutions of bromhexine hydrochloride for plotting the antilog E/S (Y-axis) against volume of standard bromhexine hydrochloride (X-axis). Fig. (10, 11, 12 and 13) represents the results of bromhexine hydrochloride concentrations 
calculated via the electrodes based on $\mathrm{BHH}$ -

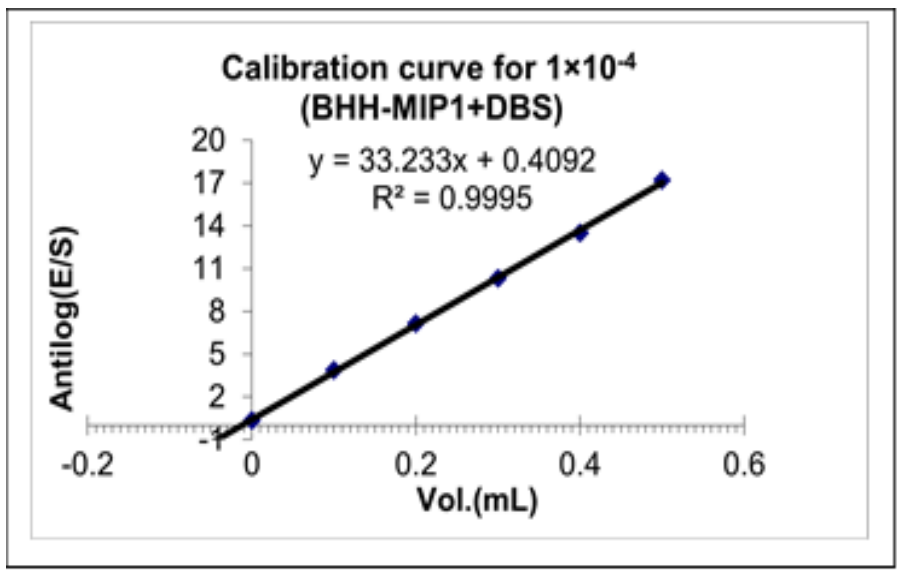

MIP1+ DBS, BHH-MIP2+TEHP

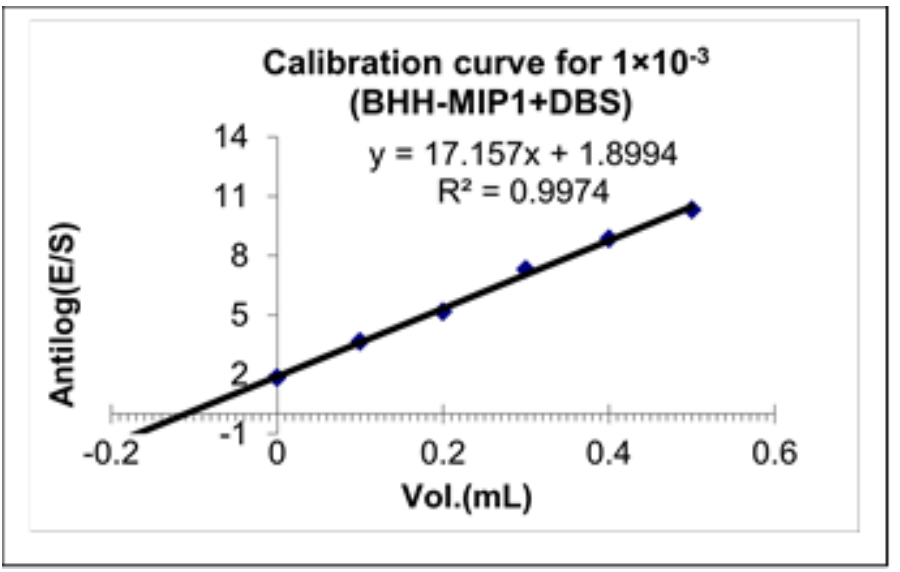

Fig.10. Antilog (E / S) against the volume of the added standard for the determination of bromhexine hydrochloride solution $\left(1 \times 10^{-3}\right.$ and $\left.1 \times 10^{-4}\right)$ by MSA using (BHH-MIP1 + DBS) electrode
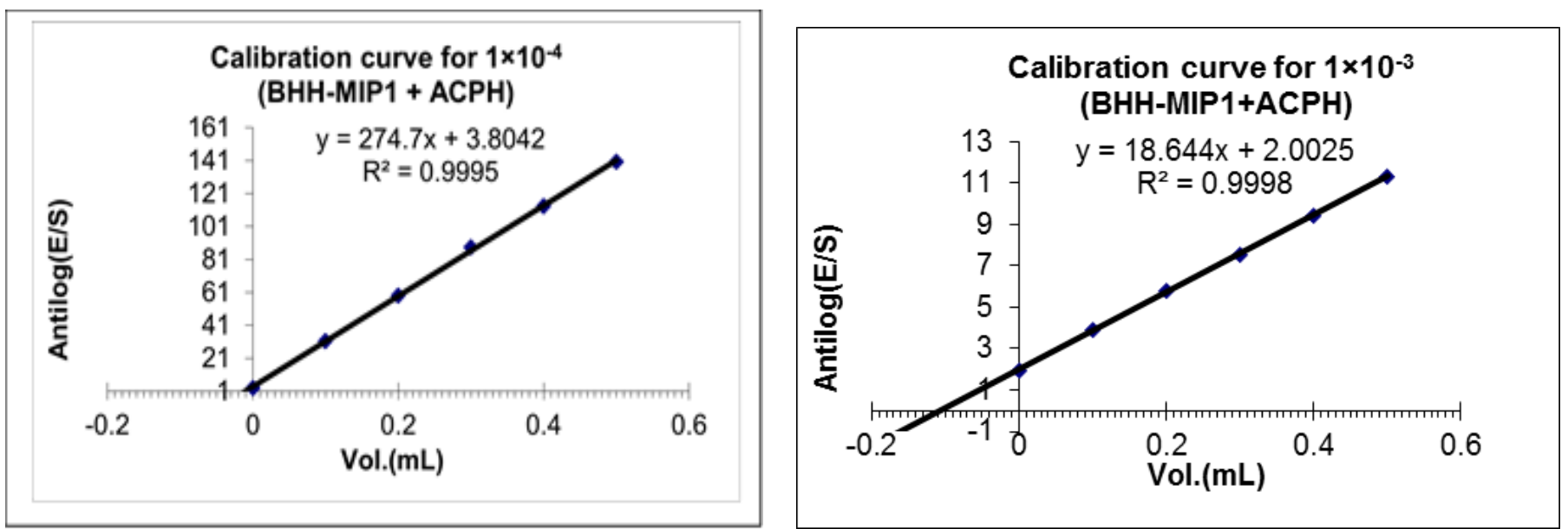

Fig.11. Antilog (E / S) against the volume of the added standard for the determination of bromhexine hydrochloride solution $\left(1 \times 10^{-3}\right.$ and $\left.1 \times 10^{-4}\right)$ by MSA using (BHH-MIP1 + ACPH) electrode
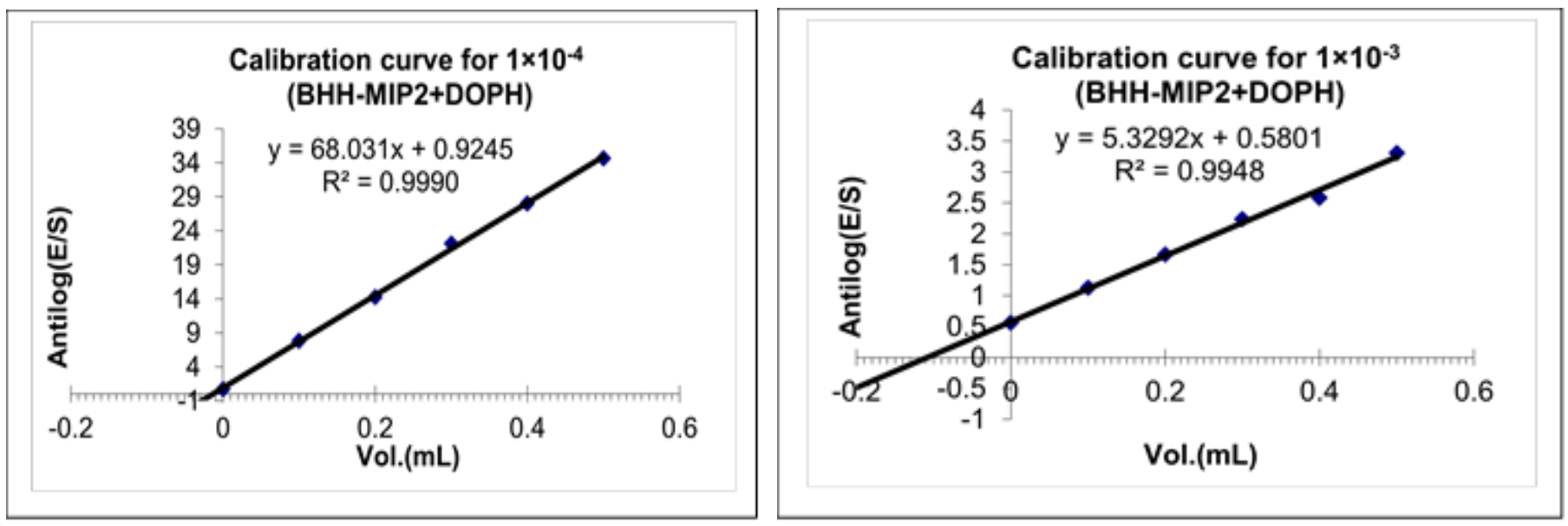

Fig.12. Antilog (E / S) against the volume of the added standard for the determination of bromhexine hydrochloride solution $\left(1 \times 10^{-3}\right.$ and $\left.1 \times 10^{-4}\right)$ by MSA using (BHH-MIP2 +DOPH) electrode 

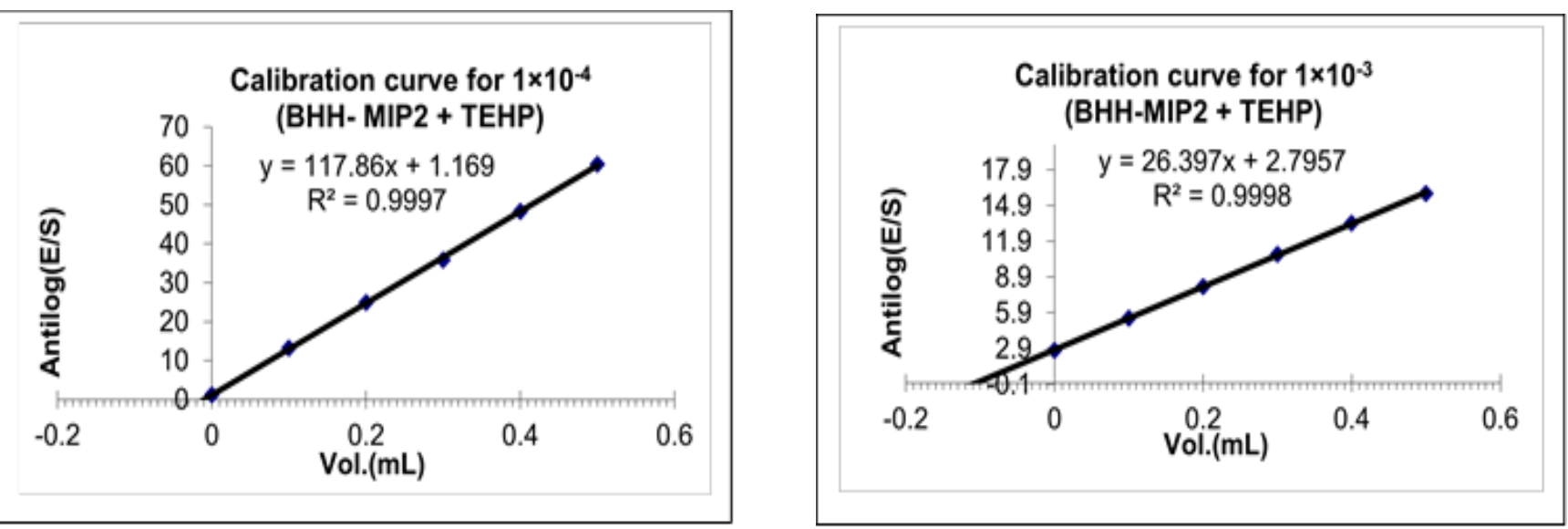

Fig.13. Antilog (E / S) against the volume of the added standard for the determination of bromhexine hydrochloride solution $\left(1 \times 10^{-3}\right.$ and $\left.1 \times 10^{-4}\right)$ by MSA using (BHH-MIP2 +TEHP) electrode

\section{Titration methods (Titrimetry)}

In this method the measurement is depended changes that to be a large shift in the electrode response for the detection of the end point of titration. The process has been achieved by used volumetric analysis of concentrations $\left(1 \times 10^{-3}\right.$ and $\left.1 \times 10^{-4}\right) \quad \mathrm{M}$ of bromhexine hydrochloride versus solutions $\left(1 \times 10^{-3}\right.$ and $\left.1 \times 10^{-4}\right) \mathrm{M}$ of concentrations (PMA). The results for parameters $\mathrm{RSD} \%, \mathrm{RC} \%$ and $\mathrm{RE} \%$ for all electrodes are listed in the table (7).

Table 7. Bromhexine hydrochloride sample analyses by using titration method for $\mathrm{BHH}$ electrodes

\begin{tabular}{||c|c|c|}
\hline Electrode No. & \multicolumn{2}{|c|}{ Concentration (M) } \\
\hline \multirow{4}{*}{ BHH - MIP1 + DBS } & Sample & $\begin{array}{c}\text { Measured using } \\
\text { PMA as titrant }\end{array}$ \\
\cline { 2 - 3 } & $1 \times \mathbf{1 0}^{-3}$ & $1.0485 \times 10^{-3}$ \\
\cline { 2 - 3 } & RSD\% & 2.10 \\
\cline { 2 - 3 } & RC\% & 104.85 \\
\cline { 2 - 3 } & RE\% & 4.85 \\
\cline { 2 - 3 } & $1 \times 10^{-4}$ & $1.0413 \times 10^{-4}$ \\
\cline { 2 - 3 } & RSD\% & 3.336 \\
\cline { 2 - 3 } & RC\% & 104.13 \\
\cline { 2 - 3 } ACPH (2) & RE\% & 4.13 \\
\hline \multirow{5}{*}{ MIP +} & $1 \times 10^{-3}$ & $1.00384 \times 10^{-3}$ \\
\cline { 2 - 3 } & RSD\% & 2.77 \\
\cline { 2 - 3 } & RC\% & 103.73 \\
\cline { 2 - 3 } & RE\% & 3.73 \\
\cline { 2 - 3 } & $1 \times 10^{-4}$ & $1.0456 \times 10^{-4}$ \\
\cline { 2 - 3 } & RSD\% & 2.156 \\
\cline { 2 - 3 } & RC\% & 104.56 \\
\cline { 2 - 3 } & RE\% & 4.56 \\
\hline
\end{tabular}

Applications of pharmaceuticals

Ion selective electrodes that based on molecularly imprinted polymers were used for determination of bromhexine hydrochloride in pharmaceuticals. This ISEs measurements including: standard addition, direct, Gran plot and multiple standard addition method.

\begin{tabular}{|c|c|c|}
\hline Electrode No. & \multicolumn{2}{|c|}{ Concentration (M) } \\
\hline \multirow{9}{*}{$\begin{array}{c}\text { BHH - MIP2 + } \\
\text { DOPH (1) }\end{array}$} & Sample & $\begin{array}{l}\text { Measured using } \\
\text { PMA as titrant }\end{array}$ \\
\hline & $1 \times 10^{-3}$ & $1.0411 \times 10^{-3}$ \\
\hline & RSD \% & 2.63 \\
\hline & $\mathrm{RC} \%$ & 104.11 \\
\hline & RE\% & 4.11 \\
\hline & $1 \times 10^{-4}$ & $0.9609 \times 10^{-4}$ \\
\hline & RSD\% & 2.24 \\
\hline & $\mathrm{RC} \%$ & 96.09 \\
\hline & RE\% & -3.91 \\
\hline & $1 \times 10^{-3}$ & $1.019 \times 10^{-3}$ \\
\hline & RSD\% & 2.64 \\
\hline BHH - MIP2 + & $\mathrm{RC} \%$ & 101.9 \\
\hline & RE\% & 1.9 \\
\hline & $1 \times 10^{-4}$ & $0.993 \times 10^{-4}$ \\
\hline & RSD \% & 3.92 \\
\hline & $\mathrm{RC} \%$ & 99.3 \\
\hline & RE\% & -0.7 \\
\hline
\end{tabular}

Preparation solutions of bromhexine hydrochloride at concentrations $1 \times 10^{-3}$ and $1 \times 10^{-4} \mathrm{M}$. The RE\%, RC\% and RSD\% were calculated of bromhexine hydrochloride in pharmaceuticals. The results obtained represented in the table $(9,10,11$, and 12). 
Table 8. Determination of Bromhexine hydrochloride Samples by Ion Selective electrodes (ISEs) techniques based on PVC membranes.

\begin{tabular}{|c|c|c|c|c|}
\hline \multirow[t]{3}{*}{ Electrode No. } & \multicolumn{4}{|c|}{ Concentrations (M) } \\
\hline & \multirow[t]{2}{*}{ Sample } & \multicolumn{3}{|c|}{ Measurements using potentiometric methods } \\
\hline & & Direct & SAM & MSA \\
\hline & $1 \times 10^{-3}$ & $0.9663 \times 10^{-3}$ & $0.9975 \times 10^{-3}$ & $1.0089 \times 10^{-3}$ \\
\hline BHH - MIP $1+$ & ${ }^{*}$ RSD\% & 3.33 & 4.84 & ---------- \\
\hline DBS & REC\% & 96.63 & 98.86 & 100.89 \\
\hline \multirow[t]{5}{*}{ (1) } & RE\% & -3.37 & -1.14 & 0.89 \\
\hline & $1 \times 10^{-4}$ & $0.9666 \times 10^{-4}$ & $0.9710 \times 10^{-4}$ & $0.9905 \times 10^{-4}$ \\
\hline & *RSD\% & 2.55 & 3.78 & ----------- \\
\hline & REC\% & 96.66 & 97.11 & 99.05 \\
\hline & $\mathbf{R E} \%$ & -3.34 & -2.89 & -0.95 \\
\hline \multirow[t]{3}{*}{ Electrode No. } & \multicolumn{4}{|c|}{ Concentrations $(\mathrm{M})$} \\
\hline & & \multicolumn{3}{|c|}{ Measurements using potentiometric methods } \\
\hline & Sample & Direct & SAM & MSA \\
\hline & $1 \times 10^{-3}$ & $0.9768 \times 10^{-3}$ & $0.986 \times 10^{-3}$ & $0.982 \times 10^{-3}$ \\
\hline ВНH - MIP1+ & *RSD\% & 2.25 & 1.15 & -------- \\
\hline АСРH & RC\% & 97.68 & 98.67 & 98.20 \\
\hline \multirow{5}{*}{ (2) } & $\mathbf{R E} \%$ & -2.32 & -1.33 & -1.77 \\
\hline & $1 \times 10^{-4}$ & $1.0238 \times 10^{-4}$ & $0.985 \times 10^{-4}$ & $0.998 \times 10^{-4}$ \\
\hline & ${ }^{*} \mathbf{R S D} \%$ & 2.82 & 1.13 & ---------- \\
\hline & $\mathbf{R C} \%$ & 102.38 & 98.57 & 99.84 \\
\hline & RE\% & 2.38 & -1.43 & -0.16 \\
\hline Electrode No. & \multicolumn{4}{|c|}{ Concentrations (M) } \\
\hline & \multirow[t]{2}{*}{ Sample } & \multicolumn{3}{|c|}{ Measurements using potentiometric methods } \\
\hline & & Direct & SAM & MSA \\
\hline \multirow{8}{*}{$\begin{array}{c}\text { BHH - MIP2+ } \\
\text { DOPH } \\
\text { (1) }\end{array}$} & $1 \times 10^{-3}$ & $1.0563 \times 10^{-3}$ & $1.0157 \times 10^{-3}$ & $0.9888 \times 10^{-3}$ \\
\hline & ${ }^{*} \mathbf{R S D} \%$ & 0.59 & 3.36 & ---------- \\
\hline & REC\% & 105.63 & 101.57 & 98.88 \\
\hline & RE\% & 5.63 & 1.57 & -1.12 \\
\hline & $1 \times 10^{-4}$ & $1.0336 \times 10^{-4}$ & $1.0195 \times 10^{-4}$ & $1.0166 \times 10^{-4}$ \\
\hline & *RSD\% & 0.92 & 4.16 & ----------- \\
\hline & REC\% & 103.36 & 101.95 & 101.66 \\
\hline & RE\% & 3.36 & 1.95 & 1.66 \\
\hline \multirow[t]{4}{*}{ Electrode No. } & \multicolumn{4}{|c|}{ Concentrations (M) } \\
\hline & \multirow[t]{2}{*}{ Sample } & \multicolumn{3}{|c|}{ Measurements using potentiometric methods } \\
\hline & & Direct & SAM & MSA \\
\hline & $1 \times 10^{-3}$ & $0.9714 \times 10^{-3}$ & $0.968 \times 10^{-3}$ & $0.982 \times 10^{-3}$ \\
\hline \multirow{7}{*}{$\begin{array}{c}\text { BHH - MIP2+ } \\
\text { TEHP }\end{array}$} & ${ }^{*}$ RSD\% & 3.71 & 0.02 & ---------. \\
\hline & RC\% & 97.14 & 96.80 & 98.20 \\
\hline & RE\% & -2.86 & -3.2 & -1.77 \\
\hline & $1 \times 10^{-4}$ & $0.9810 \times 10^{-4}$ & $0.957 \times 10^{-4}$ & $0.988 \times 10^{-4}$ \\
\hline & *RSD\% & 1.58 & 0.036 & ---------. \\
\hline & RC\% & 98.10 & 95.7 & 98.80 \\
\hline & RE\% & -1.90 & -4.3 & -1.20 \\
\hline
\end{tabular}


Table 9. Sample Analysis of Pharmaceuticals Bromhexine Hydrochloride by using ISE

\begin{tabular}{|c|c|c|c|c|}
\hline \multirow[t]{2}{*}{ Pharmaceutical } & \multicolumn{4}{|c|}{ Samarra (Iraq) } \\
\hline & Direct method & SAM & MSA & Titration method \\
\hline $\begin{array}{l}\text { Concentration prepared } \\
{ }^{*} \text { Found }\end{array}$ & $\begin{array}{c}1 \times 10^{-3} \\
0.9624 \times 10^{-3}\end{array}$ & $\begin{array}{c}1 \times 10^{-3} \\
1.0121 \times 10^{-3}\end{array}$ & $\begin{array}{c}1 \times 10^{-3} \\
1.0056 \times 10^{-3}\end{array}$ & $\begin{array}{c}1 \times 10^{-3} \\
1.0494 \times 10^{-3}\end{array}$ \\
\hline REC \% & 96.24 & 101.21 & 100.56 & 104.94 \\
\hline RE\% & -3.76 & 1.21 & 0.56 & 4.94 \\
\hline "RSD\% & 4.09 & 4.61 & ------ & 3.67 \\
\hline F experimental & 7.86 & 2.41 & ------ & 9.00 \\
\hline F theoretical & & & & \\
\hline \multirow[t]{2}{*}{ Pharmaceutical } & \multicolumn{4}{|c|}{ Samarra (Iraq) } \\
\hline & Direct method & SAM & MSA & Titration method \\
\hline $\begin{array}{l}\text { Concentration prepared } \\
{ }^{*} \text { Found }\end{array}$ & $\begin{array}{c}1 \times 10^{-4} \\
0.9631 \times 10^{-4}\end{array}$ & $\begin{array}{c}1 \times 10^{-4} \\
1.0156 \times 10^{-4}\end{array}$ & $\begin{array}{c}1 \times 10^{-4} \\
1.0041 \times 10^{-4}\end{array}$ & $\begin{array}{c}1 \times 10^{-4} \\
1.0287 \times 10^{-4}\end{array}$ \\
\hline REC\% & 96.31 & 101.56 & 100.41 & 102.87 \\
\hline RE\% & -3.69 & 1.56 & 0.41 & 2.87 \\
\hline${ }^{*}$ RSD\% & 4.90 & 3.68 & ------ & 4.36 \\
\hline F experimental & 5.70 & 3.24 & -----1- & 5.06 \\
\hline F theoretical & \multicolumn{4}{|c|}{19.2} \\
\hline
\end{tabular}

Table 10. Sample Analysis of Pharmaceuticals Bromhexine Hydrochloride by using ISE.

\begin{tabular}{|c|c|c|c|c|}
\hline \multirow[t]{2}{*}{ Pharmaceutical } & \multicolumn{4}{|c|}{ Samarra (Iraq) } \\
\hline & Direct method & SAM & MSA & Titration method \\
\hline $\begin{array}{c}\text { Concentration } \\
\text { prepared }\end{array}$ & $1 \times 10^{-3}$ & $1 \times 10^{-3}$ & $1 \times 10^{-3}$ & $1 \times 10^{-3}$ \\
\hline${ }^{*}$ Found & $0.9769 \times 10^{-3}$ & $0.9779 \times 10^{-3}$ & $1.0145 \times 10^{-3}$ & $1.0339 \times 10^{-3}$ \\
\hline REC\% & 97.69 & 97.80 & 101.45 & 103.39 \\
\hline RE\% & -2.31 & -2.20 & 1.45 & 3.39 \\
\hline${ }^{*} \mathbf{R S D} \%$ & 3.20 & 2.94 & ------ & 2.68 \\
\hline F experimental & 12.0 & 3.37 & ------ & 12.4 \\
\hline F theoretical & & & & \\
\hline \multirow[t]{2}{*}{ Pharmaceutical } & \multicolumn{4}{|c|}{ Samarra (Iraq) } \\
\hline & Direct method & SAM & MSA & Titration method \\
\hline $\begin{array}{l}\text { Concentration } \\
\text { prepared }\end{array}$ & $1 \times 10^{-4}$ & $1 \times 10^{-4}$ & $1 \times 10^{-4}$ & $1 \times 10^{-4}$ \\
\hline *Found & $0.9715 \times 10^{-4}$ & $0.9896 \times 10^{-4}$ & $0.9938 \times 10^{-4}$ & $1.0341 \times 10^{-4}$ \\
\hline REC\% & 97.15 & 98.96 & 99.38 & 103.41 \\
\hline RE\% & -2.85 & -1.04 & -0.62 & 3.41 \\
\hline${ }^{*} \mathbf{R S D} \%$ & 3.00 & 1.51 & ------ & 1.13 \\
\hline F experimental & 11.7 & 8.1 & ------ & 18 \\
\hline F theoretical & \multicolumn{4}{|c|}{19.2} \\
\hline
\end{tabular}


Table 11. Sample Analysis of Pharmaceuticals Bromhexine hydrochloride by using ISE

\begin{tabular}{|c|c|c|c|c|}
\hline \multirow[t]{2}{*}{ Pharmaceutical } & \multicolumn{4}{|c|}{ Samarra (Iraq) } \\
\hline & Direct method & SAM & MSA & Titration method \\
\hline Concentration prepared & $1 \times 10^{-3}$ & $1 \times 10^{-3}$ & $1 \times 10^{-3}$ & $1 \times 10^{-3}$ \\
\hline "Found & $0.9686 \times 10^{-3}$ & $1.0227 \times 10^{-3}$ & $0.9784 \times 10^{-3}$ & $0.9617 \times 10^{-3}$ \\
\hline REC\% & 96.55 & 102.27 & 97.84 & 96.12 \\
\hline RE\% & -3.45 & 2.27 & -2.16 & -3.88 \\
\hline "RSD\% & 0.99 & 4.30 & ------- & 2.66 \\
\hline F experimental & 3.2 & 16.2 & ------ & 13.5 \\
\hline F theoretical & & & & \\
\hline \multirow[t]{2}{*}{ Pharmaceutical } & \multicolumn{4}{|c|}{ Samarra (Iraq) } \\
\hline & Direct method & SAM & MSA & Titration method \\
\hline Concentration prepared & $1 \times 10^{-4}$ & $1 \times 10^{-4}$ & $1 \times 10^{-4}$ & $1 \times 10^{-4}$ \\
\hline "Found & $0.9573 \times 10^{-4}$ & $0.9707 \times 10^{-4}$ & $0.9863 \times 10^{-4}$ & $1.044 \times 10^{-4}$ \\
\hline REC\% & 95.73 & 97.08 & 98.63 & 104.40 \\
\hline RE\% & -4.27 & -2.92 & -1.37 & 4.40 \\
\hline "RSD\% & 0.32 & 1.49 & ------ & 2.22 \\
\hline F experimental & 16.2 & 13.6 & ------ & 18.4 \\
\hline F theoretical & \multicolumn{4}{|c|}{19.2} \\
\hline
\end{tabular}

Table 12. Sample Analysis of Pharmaceuticals Bromhexine Hydrochloride by using ISE

\begin{tabular}{|c|c|c|c|c|}
\hline \multirow[t]{2}{*}{ Pharmaceutical } & \multicolumn{4}{|c|}{ Samarra (Iraq) } \\
\hline & Direct method & SAM & MSA & Titration method \\
\hline $\begin{array}{c}\text { Concentration prepared } \\
{ }^{*} \text { Found }\end{array}$ & $\begin{array}{c}1 \times 10^{-3} \\
0.979 \times 10^{-3}\end{array}$ & $\begin{array}{c}1 \times 10^{-3} \\
0.991 \times 10^{-3}\end{array}$ & $\begin{array}{c}1 \times 10^{-3} \\
0.994 \times 10^{-3}\end{array}$ & $\begin{array}{c}1 \times 10^{-3} \\
1.011 \times 10^{-3}\end{array}$ \\
\hline $\mathrm{RC} \%$ & 97.99 & 99.16 & 99.47 & 101.16 \\
\hline $\mathrm{RE} \%$ & -2.01 & -0.84 & -0.53 & 1.16 \\
\hline "RSD\% & 2.84 & 0.88 & ------ & 3.71 \\
\hline F experimental & 8.6 & 13.7 & ------ & 4.6 \\
\hline $\mathrm{F}$ theoretical & & & & \\
\hline \multirow[t]{2}{*}{ Pharmaceutical } & \multicolumn{4}{|c|}{ Samarra (Iraq) } \\
\hline & Direct method & SAM & MSA & Titration method \\
\hline Concentration prepared & $1 \times 10^{-4}$ & $1 \times 10^{-4}$ & $1 \times 10^{-4}$ & $1 \times 10^{-4}$ \\
\hline Found & $0.972 \times 10^{-4}$ & $1.022 \times 10^{-4}$ & $1.010 \times 10^{-4}$ & $1.025 \times 10^{-4}$ \\
\hline $\mathrm{RC} \%$ & 97.22 & 102.26 & 101.02 & 102.56 \\
\hline RE\% & -2.78 & 2.26 & 1.02 & 2.56 \\
\hline "RSD\% & 2.32 & 2.04 & ------ & 1.61 \\
\hline F experimental & 13.6 & 5.9 & --0--0.- & 3.2 \\
\hline$F$ theoretical & \multicolumn{4}{|c|}{19.2} \\
\hline
\end{tabular}

\section{Conclusion}

Bromhexine hydrochloride membranes selective electrodes can be constructed by mixing with different plasticizers. These plasticizers DBS, ACPH, DOPH and TEHP were used to prepared bromhexine 
hydrochloride membranes electrodes based on PVC. The results obtained for all electrodes were excellent as well as applied on standard and pharmaceutical solutions. The aim of construction electrodes for used in determination bromhexine hydrochloride in pharmaceuticals analysis

\section{REFERENCES}

1. Al-Bayati, Y. K. and F. I. Al-jabari. 2015. Construction of new selective electrodes for determination ibuprofen and their application in pharmaceutical samples. IJCRGG, ISSN: 2231-2781, 5(3): 380-389

2. Al-Bayati, Y. K. and I. H. Al Khafaji. 2017. Synthesis of New Selective Electrodes for the Determination of Metronidazole Benzoate (MNZB) Based on a Molecularly Imprinted Polymer Combined with Poly Vinyl Chloride. IJCRGG, ISSN: 0974-4290, 10(3): 552-561

3. Al-Bayati, Y. K. and R. R. Karabat. 2015. Potentiometric study of phenytoin - pvc membrane electrodes for determination of phenytoin in pharmaceutical preparations. Journal of Al-Nahrain University. 18(1): 79-87 4. Al-Bayati, Y. K., K. H. Al-Saidi and M. A. Hussain. 2016. Liquid selective electrodes for warfarin sodium based on poly (vinyl chloride) matrix membrane. Asian Journal of Chemistry. 28(9): 1962-1966

5. Douglas A. S., D. M. West, F. J. Holler, and S. R. Crouch. 2007. "Principles of Instrumental Analsis"6th Edition, Thomson Brooks/Cole, Publisher, David Harris, Canada. pp: 665

6. Fahy, J.V. and B.F. Dickey. 2010. Airway mucus function and dysfunction. New England Journal of Medicine. 363(23): 2233-47

7. Ganjali, M. R., P. Norouzi, A. Atrian, F. Faridbod, S. Meghdadi and M. Giahi. 2009. Neutral N, N'-bis (2-pyridinecarboxamide)-1, 2-ethane as sensing material for determination of lutetium (III) ions in biological and environmental samples. Materials Science and Engineering. 29(1): 205-10

8. Ghenidii, K. 2011. "Chemical Sensors Comprehensive Sensors Technologies. Volume 5: Electrochemical and Optical Sensors" Momentum Press®, LLC, New York, pp: 131-144

9. Gupta, V. K., A. Singh and B. Gupta. 2006. A cerium (III) selective polyvinyl chloride membrane sensor based on a Schiff base complex of N, N'-bis [2-(salicylideneamino) ethyl] ethane-1, 2-diamine. Analytica chimica acta. 575(2): 198-204

10. Janata, J. 2009. Principles of Chemical Sensors $2^{\text {nd }}$ edition, Springer Science + Business Media, LLC. p: (138-148).

11. Jiang, Q., F. Nie and J. Lu. 2008. Chemiluminescence determination of bromhexine hydrochloride with morin as chemiluminescent reagent. Luminescence. 23(1): 32-6

12. Kong, D., S. Huang, J. Cheng, Q. Zhuang, Y. Liu and C.H. Lu. 2018. Sensitive determination of bromhexine hydrochloride based on its quenching effect on luminol/H2O2 electrochemiluminescence system. Luminescence. 33(4): 698-703

13. Mahajan, R. K. and P. Sood. 2007. Novel Copper (II)-selective electrode based on 2, 2': 5', 2"'-terthiophene in PVC matrix. Int J Electrochem Sci. 2: 832-47

14. Mahood, A., M.J. Hamzah and R.M. Taqi. 2017. A new spectrophotometric method for determination of bromhexine hydrochloride (BX. HCL) in pure and dosage forms using prussain blue complex reaction. International Journal of Pharmaceutical Sciences Review and Research. 43(2): 156-60

15. Moody, G. J. and J. Thomas. 1988. Organic sensor materials in entangled and polymer-bound matrices for ion-selective electrodes. Chemical Sensors: 75-116

16. Mounika, K. and L.A. Rao. 2016. Development and validation of RP-HPLC method for simultaneous estimation of bromhexine and erythromycin in bulk and pharmaceutical dosage forms. Indian Journal of Pharmacy and Pharmacology. 3(2): 63-8

17. Pharmacopoeia B. 2014. British Pharmacopoeia Commission Secretariat, Part of the Medicines and Healthcare Products Regulatory Agency. pp: 186

18. Sumarlik, E. and G. Indrayanto. 2004. TLC densitometric determination of bromhexine hydrochloride in pharmaceuticals, and its validation. Journal of liquid chromatography \& related technologies. 27(13): 2047-56

19. Vishaljain, MC.S. 2016. Validated RPHPLC method for determination of bromhexine. $\mathrm{HCl}$, chlorpheniramine maleate, dextromethorphan $\mathrm{HBr}$ and guaiphenesin in 
pharmaceutical dosage forms. Journal of Taibah University for Science. 10(1): 38-45 20. Wroblewski, W., A. Dybko, E. Malinowska and Z. Brzozka. 2004. Towards advanced chemical microsensors-an overview. Talanta. 63(1): 33-39.

21. Zamani, H. A., M. R. Ganjali, P. Norouzi, A. Tadjarodi and E. Shahsavani. 2008. Determination of terbium (III) ions in phosphate rock samples by a Tb3+-PVC membrane sensor based on N, N-Dimethyl-N', $\mathrm{N}$ "-bis (4-methoxyphenyl) phosphoramidate. Materials Science and Engineering. 28(8): 1489-94

22. Zanasi, A., M. Mazzolini and A. A. Kantar. 2017. Reappraisal of the mucoactive activity and clinical efficacy of bromhexine. Multidisciplinary respiratory medicine. 12(1): 7. 